\title{
Disloyalty and Logics of Fratricide in Civil War: Executions of Officers in Republican Spain, 1936-1939 ${ }^{1}$
}

\author{
Theodore McLauchlin, Université de Montréal \\ Álvaro La Parra-Pérez, Weber State University \\ Preprint. Comparative Political Studies 52, no. 7 (2019) : 1028-1058.
}

\begin{abstract}
Violence within armed groups in civil wars is important and understudied. Linking literatures on civil war violence and military politics, this paper examines the conditions in which this fratricidal violence is narrowly selective or arbitrary with respect to concrete disloyal behavior. It uses a unique dataset of executions of officers on the Republican side of the Spanish Civil War. The paper finds that while much of the violence appeared to target those who actually tried to defect, many non-defectors were likely shot too, due most likely to a pervasive stereotype that officers in general were disloyal to the Republic. This stereotype was used as an information shortcut, and was promoted by political actors. Accordingly, unlikely defectors were likelier to be shot in locations in which less information was available about loyalties and in which political forces that were suspicious of officers as a group were locally stronger.
\end{abstract}

\footnotetext{
${ }^{1}$ We are in immense debt to the late Carlos Engel, who generously shared his data with us. Jun Koga Sudduth also graciously made her purges data available in advance, for which we thank her. We also thank Laia Balcells, Daniel Fedorowycz, Stathis Kalyvas, Anastasia Shesterinina, and audiences at the Conference on Micro-Comparative Analyses of $20^{\text {th }}$ Century Conflicts, APSA, ISA, Universidad Austral de Rosario, Utah State, and Weber State, for extremely helpful advice and feedback. Alejandro Ángel Tapias provided excellent research assistance. McLauchlin's research was funded by the Fonds québécois de la recherche: société et culture, project 2016-NP-189322. La Parra-Pérez is a member of the research project "La crisis española de 1917: contexto internacional e implicaciones domésticas" funded by Ministerio de Economía, Industria y Competitividad of Spain, reference HAR2015-68348-R.
} 
The Spanish Civil War (henceforth, SCW) claimed some 200,000 victims among soldiers and about the same number of civilians (Preston 2012, xi). Among the dead were about 1,400 members of the Spanish officer corps who were executed, ${ }^{2}$ mainly, though not exclusively, by the incumbent Spanish Republic. The Republican toll represented almost one quarter of the officers who remained on Republican territory after the coup attempt of 18 July 1936 that started the war. Why these executions? Who was targeted for execution and on what basis? Were victims by and large selected for disloyal behavior or for other reasons, related to stereotypes about disloyalty or to the vagaries of personal enmity? This paper seeks to uncover the logics of violence against one's own military personnel, with a focus on officers. We examine in particular whether and when executioners narrowly targeted defectors and when they killed even those officers who had remained loyal. We have to assess officers' likelihood of defection indirectly, using a new microdata set to estimate their probability of joining the coup. We find that the executed included many officers who had probably tried to defect - and many who had probably not. While executions of defectors have a clear strategic logic, the killings of loyal officers demand explanation. They weaken an armed group directly, and undermine whatever deterrent effect punishing disloyalty may have. Hence their logic is not immediately obvious. We find evidence suggesting that these executions were driven by a stereotype that officers were disloyal to the Republic. Violence against unlikely defectors occurred mainly in places where it was hard to discern officers' loyalties and so stereotypes could be used as an information shortcut, and where political actors seeking to promote this stereotype had a strong presence.

The execution of one's own military personnel - fratricide or internecine violencepresents a fairly new empirical puzzle in civil war research. The study of violence in civil wars focuses on violence against civilians above all (for a review, see Kalyvas 2012). But recent studies hint that fratricide can be an important phenomenon. Factions within the same broad "side" often compete with and fight each other (Bakke, Cunningham, and Seymour 2012; Fjelde and Nilsson 2012; McLauchlin and Pearlman 2012); indeed, violence among factions can provoke shifts in loyalty through "fratricidal flipping" (Staniland, 2012). In addition, recent research has begun to uncover the macro-level linkages between civil conflicts and elite purges, which are often violent (Roessler 2011; Braithwaite and Sudduth 2016). According to Jun Koga Sudduth's (2017) data on authoritarian regimes, we find that purges are somewhat more likely during civil war years as defined by Fearon and Laitin (2003) than during years without civil wars

\footnotetext{
${ }^{2}$ The passive voice here is unfortunate but necessary: the perpetrators are not often known and the subject of passionate debate, especially for key incidents such as the massacre at Paracuellos in November 1936. Ledesma (2007) and Ruiz (2009) offer two useful summaries of the existing narratives, studies, and challenges in understanding the Republican repression in the SCW.
} 
(the statistically significant difference according to a t-test, $p<.05$, is $13.4 \%$ vs. $9.9 \%$ ). As Kalyvas $(2006,91)$ notes, purges can occur among rebel groups as well as on the regime side, given rebels' often intense fear of infiltration by security services. In short, fratricidal violence matters and is worth investigating. An improved understanding of it can help to better characterize the processes by which armed groups lose their cohesion and fall apart.

Studying this form of violence can also improve understandings of the risks that individuals take when fighting for an armed group. Past analyses of violence against civilians have assumed that armed group members face little fratricidal violence, in comparison to civilians. Kalyvas and Kocher (2007) argue that the relative safety of armed group members reduces the collective action problem in armed group recruitment, while Zhukov (2014) suggests that this safety underlies a coherent logic of indiscriminate violence against civilians: if the armed group kills civilians indiscriminately but protects its own, collaborating with the armed group can be safer than remaining neutral. But if suspicion extends within the ranks and leads to violence even against loyal soldiers, then even military service does not guarantee protection. Violence targeting actual defectors might help keep soldiers in an armed group fighting, while violence that claims loyal soldiers may backfire and prompt further defection.

As far as we know, there has not been a systematic effort to assess who among military personnel dies from fratricide, where, and when, at a micro level, nor to statistically analyze how narrowly such killings target disloyal personnel. This paper thus represents a first effort to analyze a particularly intriguing element of a repertoire of political violence (the executions of one's own military personnel), focusing on explaining the key dimensions of targeting and frequency (Gutiérrez Sanín and Wood 2017).

Groups of military personnel, and especially officers, represent a distinctive setting for violence. Exploring this setting allows a new connection between the literatures on violence in civil wars and on military politics. Disloyalty among military officers represents a particularly sharp threat, as scholars of coups have long noted (e.g. Talmadge 2015) - meaning that an effective armed group will try to both deter this defection and to avoid provoking it. As an often relatively closed world (though see Parkinson 2013) in which people's decisions about loyalty frequently respond to those of others around them (Singh 2014), the military in particular offers a distinctive environment for information about loyalty and disloyalty, which we analyze below.

However, with allowances for some unique pathways, the mechanisms of violence at issue here have a broader relevance to any setting in which disloyalty can translate into violence. In particular, we examine how prevalent were violence against actual attempted defectors, and violence that had little such connection to actual behavior, and was instead based on stereotypes 
of disloyalty, ignorance, vendettas, or collective targeting. These logics influence several important questions: whether someone can really benefit from being loyal, or risks dying in spite of it; how armed groups come to be taken over by mutual suspicion and damaging internal conflict; what opportunities exist for the pursuit of private agendas in wartime; and how well an armed group maintains itself in the face of a common enemy.

The execution of officers in the SCW provides an especially appropriate terrain to investigate these issues. The coup attempt that started the war reinforced a legacy of deep distrust of officers in general, and of certain classes of officers in particular. In addition, the case offers a unique opportunity: by examining who successfully joined the coup attempt, we can get a picture of actual disloyalty in the Spanish army, and use it to compare with correlates of executions. This, in turn, offers a window into the links between suspicion and violence. Having a circumscribed list of possible and actual victims, as well as their characteristics, permits an innovative investigation into the bases on which victims were chosen.

This paper analyzes a dataset of over 10,000 officers serving at the start of the SCW, compiled and generously shared by the late Carlos Engel, combined with La Parra-Pérez's (2014) data on officers' pre-war careers. We introduce a method to deal with the considerable difficulty in knowing who among the executed had actually tried to defect - an information problem likely to be pervasive in studies of targeting in violence. Based upon records for officers who we know rebelled in the coup attempt that started the war (because they joined the rebels without being captured), we identify key covariates of rebellion, and we examine how well these variables predict execution in order to see how systematically violence targeted those who were actually likely to have defected.

We find evidence for both violence that was likely narrowly selective, based on officers' disloyal behavior, and for violence that likely had little to do with this behavior. Executions are generally related to predictors of defecting, suggesting that authorities often waited for an officer to try to defect before targeting him. But many officers who were very unlikely to defect were still shot. Why? This violence seems best explained by the prevailing stereotype that all officers were disloyal. Stereotypes are likeliest to take hold, we argue, in areas of low information about loyalties and through the action of organized political actors. Adapting the study of information problems in violence to executions within a military rife with suspicions of disloyalty, we focus on the signals that officers send to prove their loyalty despite a strong presumption of guilt. Thus, we first find that killings of unlikely defectors were most common in provinces with a low initial rate of participation in the coup attempt that started the $\mathrm{SCW}$, arguing that this is because staying loyal is especially telling when many of one's unit mates are defecting. Second, we find that such 
killings were also more common in provinces with a high presence of local political actors who opposed officers as a group and who therefore had strong reason to promote stereotypes of officers' disloyalty.

The results shed light on how suspicions of disloyalty and violence work in a military context. It emphasizes three major dynamics: there are strong incentives to only target defectors; stereotypes are used as information shortcuts in the absence of clear proof; but these stereotypes also have social and political origins. They are, in other words, socio-political answers to strategic questions about how to target threats. The results confirm that the dynamics of information are central to violence in civil war, with narrowly selective violence prevailing where information was relatively clear and stereotypes winning out where it was less so, by serving as an information shortcut. Our approach insists as well on the social construction of these stereotypes and the political actors underlying them.

\section{Theory: Linking Disloyalty to Violence}

The most obvious logic of executing officers has to do with punishing disloyalty. Civil conflicts clearly raise deep questions of allegiance. One of their central dynamics is identification problem about civilians who may be collaborating with the enemy (Kalyvas 2006). Soldiers may often desert or defect given the chance, as a growing literature is analyzing (Costa and Kahn 2008; McLauchlin 2010; Chenoweth and Stephan 2011; McLauchlin 2014; Lyall 2014; McLauchlin 2015; Oppenheim et al. 2015; Dahl 2016; Koehler, Ohl, and Albrecht 2016). Moreover, considering officers in particular, civil wars appear to increase the risk of coups d'état. Rebellions demonstrate the weakness of the incumbent leader and the potential support a coup might enjoy, while keeping officers in a location where a coup plot is feasible rather than sending them away (Bell and Sudduth 2015; Piplani and Talmadge 2015).

Punishing disloyalty in the armed forces is a familiar element in the literature on authoritarian rule and personalist regimes (Svolik 2012; Geddes, Wright, and Frantz 2014). Without strong central institutions to coordinate elites, political survival has a lot to do with the ability to prevent coup plots. Regime elites, military officers among them, have incentives for preference falsification (Kuran 1995) in this setting, seeking to position themselves on the winning side in inter-factional contestation while not running the risk of early detection of a plot (Singh 2014). Leaders of personalist authoritarian regimes therefore impose coup-proofing techniques: intense monitoring of officers' activities, multiple competing security services, or promoting loyalists and demoting the suspect (Brooks 1998; Quinlivan 1999; Talmadge 2015). At 
the limit, armies and other allied forces suffer denunciations and violent purges under personalist dictators such as Stalin, Hitler, Saddam Hussein and Hafiz al-Assad.

Thus a link between disloyalty and execution is an obvious place to begin, but what is the connection? It could be simply than the army punishes those who attempt to defect and are caught. But many other officers could be victims too. Where and when do officers who have not behaved disloyally and are not plotting to do so become targets?

There are compelling incentives to focus on catching and punishing officers who actually attempt defection or who actively plot to do so (narrowly selective violence). If violence is to effectively deter disloyal behavior, it must be narrowly focused on that behavior; the flipside of deterrence is assurance (Schelling 1966; Saideman and Zahar 2008). If an officer might be targeted for violence having not taken any action towards defection, he or she has little reason not to try to defect. At least in the other army there might be safety (Kalyvas 2006, 143). These strong reasons for selectivity suggest that violence should generally follow actual attempts at defection.

How, then, do loyal soldiers come to be shot? This paper focuses on stereotypes portraying groups of soldiers - in this case, the whole officer corps - as disloyal. With prevailing views that a particular group is prone to disloyalty, members of that group become more vulnerable to violence. They could be targeted pre-emptively in order to forestall their defection, particularly when there is no better information to use. At the same time, political actors who seek to weaken a group of soldiers for whatever reason-class or identity-based conflict, for example - may try to promote a stereotype, painting the group as disloyal in order to justify targeting them. This is a form of collective targeting (Steele 2009; Gutiérrez Sanín and Wood 2017) that uses collective identity as a focus for socially- and politically-produced information shortcuts about likely behavior.

The importance of information problems and of political production for the logic of stereotypes produces two arguments. First, we argue that low information about loyalties increases the likelihood that a loyal soldier will be shot, provided that there is a stereotype about the disloyalty of certain groups. In contrast, with a greater degree of information, the compelling deterrence logic of narrowly selective violence should be more likely to prevail and few soldiers should be executed absent a clear attempt to defect.

Stereotypes can serve as information shortcuts. As Kalyvas (2006, 147, 188) notes, a key step in leading from a lack of information to execution is a willingness to accept the death of innocents. When the army does not have clear proof of disloyal behavior, killing its own members means killing knowing it will make mistakes. In the context of fratricide, these deaths 
directly weaken the military and could deeply undermine deterrence. An army leadership that believes that a group of soldiers is disloyal is likely to see the risk of targeting innocents as less important, and to see the risk of letting the guilty live as too grave to run. If, however, the army has better, more fine-grained information about who is planning to defect or has attempted to do so, it should rationally use that information rather than stereotypes to inform its decisions about targeting.

Specifically, we adapt the study of information quality to an intra-military context in which officers in general often defect and are under considerable suspicion. Rather than focus on degrees of state control as a key driver of information quality, as Kalyvas (2006) does in the setting of counterinsurgency, it makes sense in analyzing the inner workings of an officer corps to examine the signals that officers send. In particular, since officers react to each other's decisions and there are strong reasons to follow the herd (Singh 2014), when an officer carries on fighting even in areas in which many fellow officers are defecting, it sends an especially strong signal of willingness to behave loyally: the officer is a loyalist, not a plotter or fence-sitter, to use Singh's $(2014,63)$ conceptualization. In contrast, in areas where few fellow officers defect, those who stay and fight may do so out of a general preference to stay, or simply out of fear of the reaction of others. Loyal behavior says less about underlying preferences when everyone else is staying loyal than when far fewer are. (This indicator would not work in every context. In armies with no major issues of disloyalty, staying loyal when others do raises no concern; it is simply the expected behavior.) In this context, we expect more killings of loyal soldiers in areas with a low incidence of defection. Counterintuitively, then, the "innocent" are safer in areas where there are more of the "guilty."

The second major argument is that where political actors who oppose a particular group of soldiers are strong, there should be a higher likelihood of violence against even loyal soldiers who belong to this group. Stereotypes can be broadly pervasive in societies but can also vary from place to place at a micro level. As Balcells (2010) argues, violence in civil conflicts can be a vehicle for local political agendas, as local political actors seek to eliminate their opponents. It is plausible that opponents may be found among combatants as much as among the civilian victims that Balcells studies, given all of the evidence that factionalism frequently riddles movements and armed groups (Bakke, Cunningham, and Seymour 2012; McLauchlin and Pearlman 2012; Staniland 2012). We therefore expect that the local strength of political actors who target officers as a group and who promote the stereotype of their disloyalty should be correlated with killings of likely loyal officers. 
How does this analysis differ from past work? We obviously draw a good deal on Kalyvas' (2006) arguments. Our approach agrees that selective violence should generally respond to strategic incentives. It further agrees about the significant role that a lack of good information plays in undermining these incentives and driving violence by stereotypes.

However, there are some important differences. While Kalyvas sees information quality in terms of the top-down apparatus of control that the state or a rebel group has over a civilian population (e.g. the presence of its troops and its institutional effectiveness), the intra-military context, particularly in the officer corps, lends itself to thinking about information in terms of how officers react to each other and the signals they send each other in their behavior. Indeed, based purely on presence and institutional capacity, we might expect better information where officers had defected less, since this would imply more personnel and more intact chains of command. ${ }^{3}$

Further, we analyze the social and political production of stereotypes in addition to the information problems that make these stereotypes attractive shortcuts. This has two empirical manifestations. First, suspicion of the entire officer corps in Spain was a general background condition established over many years. Patterns of collective targeting may look different in other armies, depending on the particular construction of stereotypes. We cannot test this hypothesis here, and we note it for future research. We can and do test a second empirical manifestation: variation in the strength of political actors can lead to variation over space within a single civil war in the strength of stereotypes, and hence in how often non-defecting officers are killed.

We also focus on a different distinction in violence than Kalyvas does. For Kalyvas (2006, 142), the key distinction between "selective" and "indiscriminate" violence against civilians concerns the process of violence. Selective violence entails "an intention to ascertain individual guilt (...)[and] personalized targeting," while in indiscriminate violence, the "selection criteria are rough" (Kalyvas 2006, 148), often involving targeting a neighbourhood or a village. However, for Kalyvas, selective violence can still entail many errors. It can target people who are simply rivals of local collaborators rather than those who are helping the enemy. Faced with this problem, "political actors turn to 'secondary' profiling (...): they look for visible features that may signal loyalty or disloyalty and separate true from false denunciations" $(2006,187)$. In other words, they use stereotypes. In each case, the result is often a high degree of mistaken killings in this category of selective violence (Kalyvas 2006, 188-89). Our concept of "narrowly selective violence" is more restrictive, focusing on those who tried to defect; we therefore also seek to

\footnotetext{
${ }^{3} \mathrm{We}$ thank an anonymous reviewer for pointing this out.
} 
explain the contrast set, the deaths of those who had never tried to leave. Hence, we essentially examine when violence matches behavior and when it does not. This question directly assesses whether an officer could have stayed safe by staying loyal.

Further, while Kalyvas (2006, 190-91) argues that even inaccurate selective violence need not undermine deterrence, because the process of selection makes people believe that the victim might really have been guilty, mistaken killings at the very least generate an additional risk that deterrence could be undermined. Further, fratricidal killings directly weaken the army whatever their deterrent effect. They therefore represent a particularly important puzzle.

This approach differs more clearly from three other possible explanations of killing loyal soldiers, which would have different empirical expectations. First, some approaches to group targeting suggest that members of a group could be targeted regardless of the quality of information about their loyalties, simply on the belief that members of a different group are threatening (Kaufmann 1996). Second, ignorance and organizational failures could lead to collective or random targeting or to mistakes despite their counterproductive consequences (Kalyvas 2006, 162-67). Finally, private interpersonal conflicts could lead to targeting of officers for reasons having nothing to do with their actually disloyal behavior. Since a false denunciation in pursuit of a private agenda can draw on a stereotype of disloyalty to gain credibility (Kalyvas 2006, 187), private conflicts represent a separate explanation for violence only to the extent that private actors have greater freedom to pursue their agendas and are hence able to target their rivals regardless of whether those rivals fit the profile.

If these three different mechanisms are more powerful than stereotypes, then we should expect killings of non-defectors even when information is good. Additionally, while the logic of group targeting would expect, as we do, that the presence of political actors who push the relevant stereotypes should correlate to killing loyal soldiers, the other explanations do not.

Note that the general climate of stereotypes of officers and fear of disloyalty that reigned in Republican Spain operates as a background condition for the variation we examine. In such a setting, actors may be especially inclined to err on the side of killing the innocent rather than sparing the guilty. In contrast, if there is little overarching stereotype of disloyalty, violence appears to be a more extreme response, weakening the army and risking creating a disloyalty problem that would not have otherwise existed. A response to a low incidence of defection might therefore be restraint in other contexts. This also means that our first argument-in the presence of stereotypes, low information leads to killings of loyalists - is not a tautology relating simply to inaccuracy. Nothing about a low-information environment requires that an army commit any fratricide at all. It does so because of decisions, particularly because of stereotypes in an 
environment of uncertainty. Because our empirical analysis is in the Spanish Republic, in which fears of disloyalty of officers were widespread, they may not travel to other contexts (indeed, we would expect them not to). All of our findings should be interpreted bearing in mind this context, to which we now turn.

\section{The Spanish officer corps in the Republic and the SCW}

Loyalty concerns were a constant theme in the Spanish officer corps. The corps was a central player and a central point of contention in the politics of the Republic in the years prior to the SCW. The Spanish Army had been an important organization in all the Spanish institutional arrangements predating the Republic. Far from being under political or civilian control, officers had traditionally acted as independent political players who committed repeated coups and deeply shaped government stability (Boyd 1979; La Parra-Perez 2016), developing an "interventionist mentality" according to Puell de la Villa (2012). Officers played a critical (even if passive) role in the founding of the Republic: after municipal elections in April 1931 gave Republican parties an unexpected victory in the bigger cities, the King realized he could not count on the explicit support of the military and fled the country.

The leftist parties that governed the Republic during its first two years set out to reshape the role of the army in society, alongside agriculture, women's rights, the separation of church and state, and - particularly troubling to many officers - the place of Spain's restive regions like Catalonia. Between 1931 and 1933, Manuel Azaña, first as Minister of War and then also as Prime Minister, passed a series of military reforms. Voluntary retirement with full pay was offered to address the problem of excess officers. Promotions within the army would be determined by strict seniority and study, and promotions by combat merit that had occurred in Spain's colonial war in Morocco (1917-1927) were cancelled. The education of technical corps (engineers and artillerymen) was separated from that of infantrymen and cavalrymen, reinforcing the institutional separation of the former. The independence and economic rewards of the Aviation corps - one of the corps most clearly opposed to Miguel Primo de Rivera's dictatorship (1923-1930) before the Republic - were increased. The Republic also created a new militarized police corps, the Assault Guards, the members of which had to be "of proven republican loyalty" (González Calleja 2012, 113), in addition to the already existing Civil Guards.

The ambitious and far-reaching reforms led to distributional tensions between military factions. Some officers' careers were negatively affected after promotions by combat merit were revised and cancelled. Infantrymen and cavalrymen resented the elimination of a unified 
education for all officers, which set the artillery and engineers apart. Notably, this reform eliminated the central military academy at Zaragoza, whose commandant was Francisco Franco. Finally, the military reforms threatened to limit military power by placing it under greater civilian control.

The discontent and disloyalty of some Spanish elites with the Republic had the first manifestation in a failed military coup in 1932. Tensions stemming from both extremes of the political spectrum kept mounting during the next four years. During the reign of a center-right coalition (1933-1935) there was a revolt in Asturias in 1934 organized by socialist trade unions that took several days to be repressed by the army, at the cost of hundreds of lives. After the Popular Front (a left-wing coalition similar to the one that ruled between 1931 and 1933) won the elections of February 1936, an escalation of political violence resulted in the murder of many politicians, activists, and members of security forces by rival radical groups. In this increasingly polarized environment, a military coup broke out in Spain's Moroccan colonies on July 17 and expanded to the Iberian Peninsula the next day, marking the beginning of the SCW.

Against the backdrop of civil war was political violence behind the lines that killed around 200,000 civilians (Preston 2012, xi). Rebel repression killed many more civilians than violence on the Republican side, but according to our data, about six times as many officers were executed on the Republican side as on the Rebel side. In the remainder of the paper, we focus on Republican-controlled territories.

Executions followed several different procedures on the Republican side. Where a garrison rose during the coup attempt but was defeated, the officers regarded as responsible were sometimes executed summarily by the loyalist officers and civilian militias. Further, facing an insurgency from an important part of the army, the Republican government gave in to demands to distribute weapons to militias often organized by unions and political parties, which resulted in "hot-blooded terror": executions without minimal judicial guarantees. These mainly took two forms: sacas and paseos. The sacas consisted of assaults on jails in which prisoners were taken and executed. The most infamous saca took place in November 1936 as the Francoist siege on Madrid began. Almost two thousand prisoners of the Cárcel Modelo of Madrid were brought to Paracuellos de Jarama (25 km. northeast of Madrid), executed, and buried in mass graves. Many of the prisoners were officers captured at the outset of the conflict in the military barracks around Madrid. The paseos ("walks" or "promenades" in Spanish) were a euphemistic way of referring to the capturing and execution of allegedly disloyal individuals. These executions were rarely subject to judicial guarantees. When there was a trial, the members of the tribunal (sometimes themselves criminals freed after the military coup) often lacked any legal training or experience. 
One infamous court was nicknamed "tribunal de la muerte" (death court) since its memberstypically drunk-invariably issued arbitrary death sentences (Preston 2012, 273, 368; see also Thomas 1961, 176-8).

Finally, Republican military authorities conducted a wide-ranging purge to remove suspect officers from their posts and to arrest many of them. Captain Eleuterio Díaz Tendero, head of the administration for assessing officers' loyalties (Gabinete de Información y Control, GIC), maintained a list of officers next to whose name he placed the label "loyal", "indifferent", or "fascist", which often meant the difference between promotion, and expulsion and arrest. The label could then make an officer vulnerable to execution, notably in sacas.

Terror had different dynamics and timings in the republican territories. Casanova (1999) notes that in 1937 "hot-blooded terror" had already tapered off in most of the Republicancontrolled areas, thanks in part to the creation of tribunales populares (people's courts), in which defendants had more systematic judicial protections. Herreros and Criado $(2009,439)$ find a significant decrease in the number of people killed in seven republican provinces when people's courts were introduced in the fall-winter of 1936. Despite regional variation in the targets of "popular" violence, officers were a target everywhere. Almost half of the victims of sacas in Republican-controlled areas and one third of total victims with known profession were army officers (Casanova, 1999: 135).

But who among the officers was targeted, and in what patterns? There is considerable anecdotal evidence for killings both of defectors and non-defectors. According to Paul Preston (2012, 268), killings frequently targeted those who actually participated in the coup attempt: "Prominent among those in danger of losing their lives in the Republican zone were army officers who had taken part in the failed coup. That was the usual punishment for mutiny." The rising hardly succeeded everywhere it was attempted; in many garrisons, it was defeated by the concerted action of pro-Republican officers and soldiers, and by rapidly organized and armed civilian militias. Once the coup participants were defeated, many were put summarily before firing squads.

However, there is considerable evidence that executioners killed non-defectors as well. First, officers in general were regarded as suspect, meaning that the distinctions among officers frequently broke down; just being an officer was enough to come under suspicion. There were at least two reasons for the targeting of officers as a category. In political imaginaries of many of the revolutionary forces that acted during the breakdown of the republican state, the military appeared as a key organization in the "old establishment". As Preston explains, "the militias of the most left-wing parties and trade unions were determined to annihilate the representatives of 
the Church, the army, the upper class and the non-liberal bourgeoisie. In other words, they aimed to create a revolutionary society to combat the military/fascist state" $(2012,266)$; it was, moreover, common to use the word "fascist" quite loosely (Payne 2006, 64). The relative importance of "uncontrolled" violence with respect to violence emanating from republican authorities is still the subject of debate (Ledesma 2007; Ruiz 2009). However, it is widely accepted that violence against rebels - uncontrolled or planned-was often exerted by leftist organizations, particularly after they were armed shortly after the beginning of the SCW. They acted through assassinations, questionable local judicial proceedings in localities these organizations took over during the summer of 1936, and in pressuring the Republican government's own repression decisions (Payne 1970, 225-26; Thomas 1961, 176, 179). In those areas in which socialists and anarchist organizations were more present, they could take advantage of the breakdown of the pre-war political order to push their political agendas and influence the way repression was conducted.

Furthermore, the coup attempt that started the war provided vivid proof that many officers were disloyal to the Republic, a judgment easily extended to officers as a class. Many remaining officers really did behave disloyally, attempting to defect. But it was not always easy to detect who would do so. Antonio Lino, secretly a rebel supporter, was named commander of the Republican Criminal Investigation Brigade. Eventually, the fear of being discovered led Lino to take refuge in the Mexican Embassy (Preston 2012, 276). A group of Civil Guards, in a Republican expedition to retake Teruel in late July 1936, murdered most of the union-organized militiamen in the group and joined the rebel ranks (Preston 2012, 251-52).

In the face of the threat of defectors like this going undetected, the GIC, in charge of assessing officers' loyalties, was quite understaffed. In the words of one of its members:

...the Ministry [of War] operated with the bare minimum personnel: the majority of officers who served in each department had disappeared; among the few that stayed, someone vanished each day either because he voluntarily left $(\ldots)$ or because it was discovered that he belonged to the UME [a conservative military organization] or to Falange [Spanish fascist political party] and if they stayed at the Ministry it would be to serve rebel interests and, naturally, he was arrested. (Cordón 2008, 410, see also p. 427) Therefore, a large percentage of disloyal officers were never detected.

Knowing that many officers were potentially disloyal but not knowing which ones could give rise to violence based on a general distrust of the army. A vivid example came at the outset of the war. The Montaña barracks outside Madrid were besieged by loyalists, and though proRepublican officers within the barracks raised the white flag, Rebel officers continued to shoot. Angry at what they regarded as a trick, loyalist militiamen killed many officers in revenge after the barracks fell—including, according to the General Staff officer José Martín Blázquez (1939, 
116), the Republicans who had tried to surrender. After the Montaña siege, officers tried to hide as civilians but were identified and shot (Fraser 1979, 78). The general hatred of officers may also have given license to personal agendas and malicious denunciation; Martín Blázquez $(1939,135)$ recounts the murder of an officer friend of his by a militiaman, for reasons of "personal vengeance."

While revenge was certainly an important motif of this general targeting of officers, there is further evidence that there was occasionally a conscious decision to accept false positives in order to reduce the number of false negatives. In his memoirs, Enrique Castro-senior Communist and Republican commander-gave the following advice to the head of a special unit in the hours before the Paracuellos massacre: "The massacre starts. No quarter to be given. Mola's Fifth Column [secret rebel units feared to be inside Republican territory] must be destroyed before it begins to move. Don't worry about making a mistake! There are times when you find yourself in front of twenty people knowing that one of them is a traitor but not which one" (Castro Delgado 1965, 390). In other words, these executioners accepted and expected that their victims would include non-defectors.

While much of this selection process did not make much distinction among officers, some subgroups came under especially intense suspicion. Many accounts suggest that certain services were targeted above all, such as the hated Guardia Civil, often responsible for the repression of the Spanish labour movement (e.g. Alpert 2013, 25; Saíz Viadero 1979, 69; González Calleja 2012, 100-111). The centralized process of assessing loyalties in the understaffed GIC and Díaz Tendero's list may well have drawn on information shortcuts.

The historical literature thus sustains very different modalities of violence against officers, from directly punishing attempted defectors to targeting officers as a class. Our statistical data cannot assess whether any given officer was executed under one or the other of these logics, but it can suggest whether there is evidence for any one of these tendencies. The next section describes the data used to make such assessments.

\section{The Spanish officer corps dataset}

Carlos Engel compiled data on the postings and wartime fates of the entire Spanish officer corps during the SCW, on the basis of official publications like military yearbooks and bulletins and a very large secondary literature (Engel 2008). He recorded whenever an officer generated a record on one side or another, for example when that officer was posted to a unit, or received a promotion, reward or punishment. Engel recorded the place, date, and manner of 
death, including by firing squad (fusilamiento), our measure of the dependent variable. With these executions, he provides a reference to a pension accorded by the postwar Franco regime to the family of the victim, indicating that the regime attributed the shooting to the Republican side. To check the reliability of these data, we cross-referenced the executions for Barcelona and Madrid (Spain's two largest cities) with Solé i Sabaté and Villarroya (1990) for the former and Casas de la Vega (1994) for the latter, finding a correspondence of $80 \%$ and $95 \%$ respectively (see appendix).

We include the 11,678 who served in the main land-force services (including the Air Force and the three paramilitary police services: Civil Guards, Assault Guards, and Carabineers). In what follows, we first analyze, across all of these officers, what were correlates of successfully joining the coup attempt at the outset of the war (i.e. without being caught and executed). We then use this model to examine whether executions on the Republican side followed patterns of actual disloyalty. Since this latter analysis focuses only on the Republican side, in conducting it we exclude anyone who successfully joined the coup attempt at the outset, or was otherwise on territory that fell immediately to rebels (such as officers who resisted the coup attempt in garrisons where it immediately succeeded). We do so in order to focus only on those officers who could have been executed by the Republic. Further details on the data and coding procedures are available in the appendix.

We complemented Engel's data for officers during the SCW with La Parra-Pérez's (2014) dataset for active officers during the Republic. This dataset uses the military yearbooks published by the Ministry of the War to gather information on officers' professional trajectory between 1931 and 1936. The dataset also identifies those officers affected by some of the 19311933 military reforms. This is the basis for our coding of pre-war career progress, a critical indicator of coup participation and execution.

The overall timing of executions of officers suggests a clear connection to fears of disloyalty. Our dataset contains 1,138 officers shot on Republican-controlled territory during the SCW. For 1,114 observations (97.9\%) Engel provides information on the date the officer was shot (Figure 1). 1,049 officers (94.2\% of those with dates) were shot before 1937, consistent with the findings for other types of repression in republican areas (against the clergy or civilians in general) that finds that the majority of killings took place during the first months of the conflict (Casanova, 1999). There were two peaks: just after the start of the war in August 1936, and then a second, somewhat larger wave in November 1936. In the latter, 336 officers (30.2\%) were executed, 222 in the massacre of Paracuellos. In each wave, a connection to fears of disloyalty is strongly plausible: in the former, punishment for participation in the coup attempt and fear of the 
same; in the latter, a fear that disloyal officers would join the Francoists as they began the siege of Madrid.

Figure 1. Officers executed in Republican-controlled areas, by month

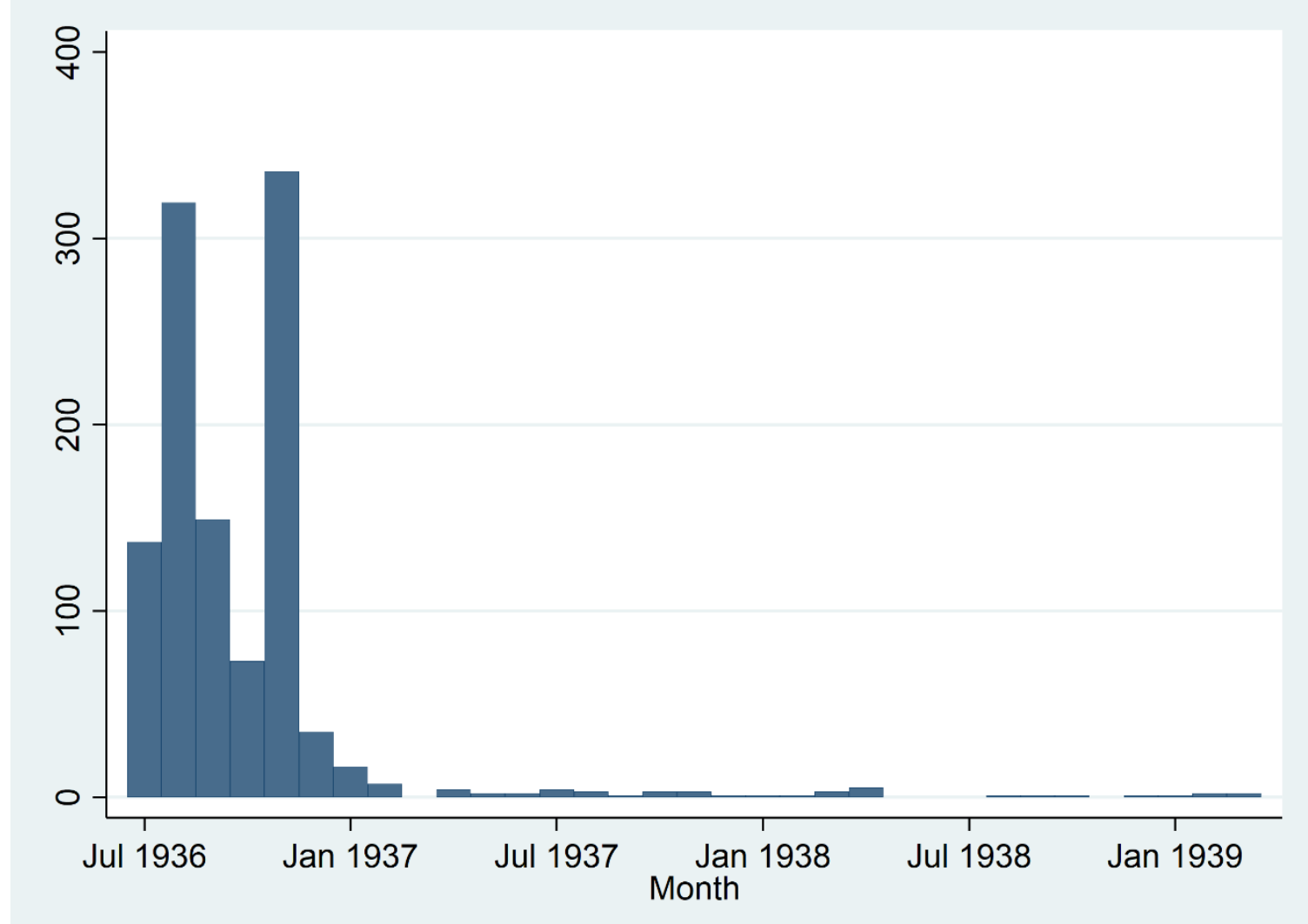

\section{Empirical Strategy and Results}

We now turn to the key empirical questions: what link is there between officers' actual disloyal behavior and violence against them? Were SCW officers generally targeted for actually trying to defect? Where were even loyal officers especially vulnerable to execution? Unfortunately, a direct test of whether executions responded to actual attempts to defect (i.e. actual disloyal behavior) is impossible. We can identify those officers who successfully defected to the rebels, but not those who attempted and were caught. So we cannot directly tell who among the executed officers had actually tried to defect. Hence, we have to pursue an indirect research strategy. Since we can determine who in the officer corps successfully joined the coup attempt at the outset, we can examine how well correlates of successful coup participation also predict executions. In the remainder of the empirical analysis, we will refer to violence against likely and unlikely defectors to reflect this uncertainty. 
We first study the overall portrait of execution in Spain to validate our general approach, and then examine geographic patterns in the overall rate and the correlates of violence: did execution victims hew closer to the profile of coup participants in some provinces than in others? By examining variations in the correspondence of coup participation to execution across provinces, we are able to assess how different logics of execution varied in prominence in different places.

\section{Who was shot? Individual correlates of coup participation and execution}

Our indirect method examines the match between correlates of initial coup participation and correlates of execution in order to assess the narrowly selective quality of execution. Narrowly selective violence means a process in which an officer intends to defect, attempts to do so, is caught and shot - a correspondence to actually disloyal behavior. The likelihood of defection is then related to the likelihood of execution, and this should be reflected in correlations between execution and characteristics that are also good predictors of defection.

Hence our basic strategy is to estimate a model of execution using, as predictor variables, these correlates of disloyal behavior. In this model, violence against unlikely defectors based on different logics - such as stereotypes that officers are disloyal, opposition to officers as a class, personal vendettas having nothing to do with disloyal behavior, and sheer organizational errorswould all be reflected in the error term. The greater the error, the more likely it is there were victims who had only ever behaved loyally.

Officers with slower recent career progress were more likely to join the coup plot. This represents a professional grievance among these officers against the Republic, driven above all by military reforms that cancelled promotions. While some officers were demoted for their political leanings, La Parra-Pérez (2014) finds that slow career progress under both left-wing and rightwing governments under the Republic predicted coup participation, suggesting that this variable taps professional interests more than political selection. The second key variable is age. The coup plotters specifically recruited young officers and focused on those who commanded combat troops, who were likelier to be young (Cardona 1983, 221-22, 235; Alpert 2013, 9). Young officers may also have been more risk-acceptant (Puell de la Villa 2012, 92-93; Cardona 1983, 143). La Parra-Pérez (2014) finds that officers with shorter tenure in the officer corps (which correlates with age at .95 ) were likelier to join the coup attempt. He has a similar finding for different corps, ranging from the paramilitary Assault Guards as the clearest loyalists to the aristocratic Cavalry as the most likely to rebel. 
There is one important concern regarding corps affiliations. While officers' different corps are an important predictor of defection, these corps had reputations for loyalty or disloyalty to the Republic, so interpreting their relationship to execution is difficult. The Assault Guards had been established as a paramilitary police force for regime maintenance while the main combat arms were seen as especially hostile to the Republic's supposed anti-militarism. The Civil Guards were hated on the Left as the agents of the repression of rural labor, and the Cavalry had a reputation as an aristocratic service branch (Cardona 1983, 107). Because of these stereotypes, there are two interpretations possible for any link between corps and executions. It might be that (for example) Cavalry officers were executed more often than Assault Guards because they were more likely to try to defect, and were caught and shot (i.e. violence was narrowly selective); or because they were seen as disloyal, whether they tried to defect or not (such that many of the victims would be non-defectors). The two critical variables for the logic of narrowly selective violence are therefore age (which, though obviously public information, was not especially subject to widespread stereotypes as far as we can see) and career progress (which would be much more difficult to keep track of for any given officer). Because there is no reason to suppose that different actors used these criteria systematically to assess loyalties, if they have a relationship to execution, it is likely because they predict officers who tried to defect, and were caught.

In order to properly estimate the relationships between the likelihood of disloyalty and execution in the model, and therefore to have a residual that really reflects executions of unlikely defectors, we have to control for other predictors of victimization. In particular, the costs of an officer's defection may drive execution. Officers with postings to units undermine those units when they defect, while high-ranking officers and unit leaders can take subordinates with them when they leave. Their defections would therefore be especially important to deter and to punish. We control for the costs of disloyalty by including rank and indicators of whether the officer was a unit leader and was posted to a unit rather than unassigned.

We estimate an overall model of successful coup participation among all 10,442 officers, across Spain, who were not executed. This model uses the variables listed above, which La ParraPérez (2014) found to be related to coup participation. We then use the same variables to estimate a model of execution among the 4,671 officers who had not successfully participated in the coup and were on Republican territory. Figure 2 permits a comparison of the two, indicating the marginal effects of a unit change (or, in the case of continuous variables, a shift from $5^{\text {th }}$ to $95^{\text {th }}$ percentile) of each independent variable on the likelihood of (a) successful coup participation and (b) execution by the Republic. The model for successful coup participation includes officers from 
across Spain, so it includes a control for whether they were in Rebel-controlled territory. In contrast, the execution model is limited to officers in Republican territory, who were "available" to be executed, so the "Rebel area" variable is dropped.

Figure 2. Marginal effects on predicted probabilities of successful coup participation and execution

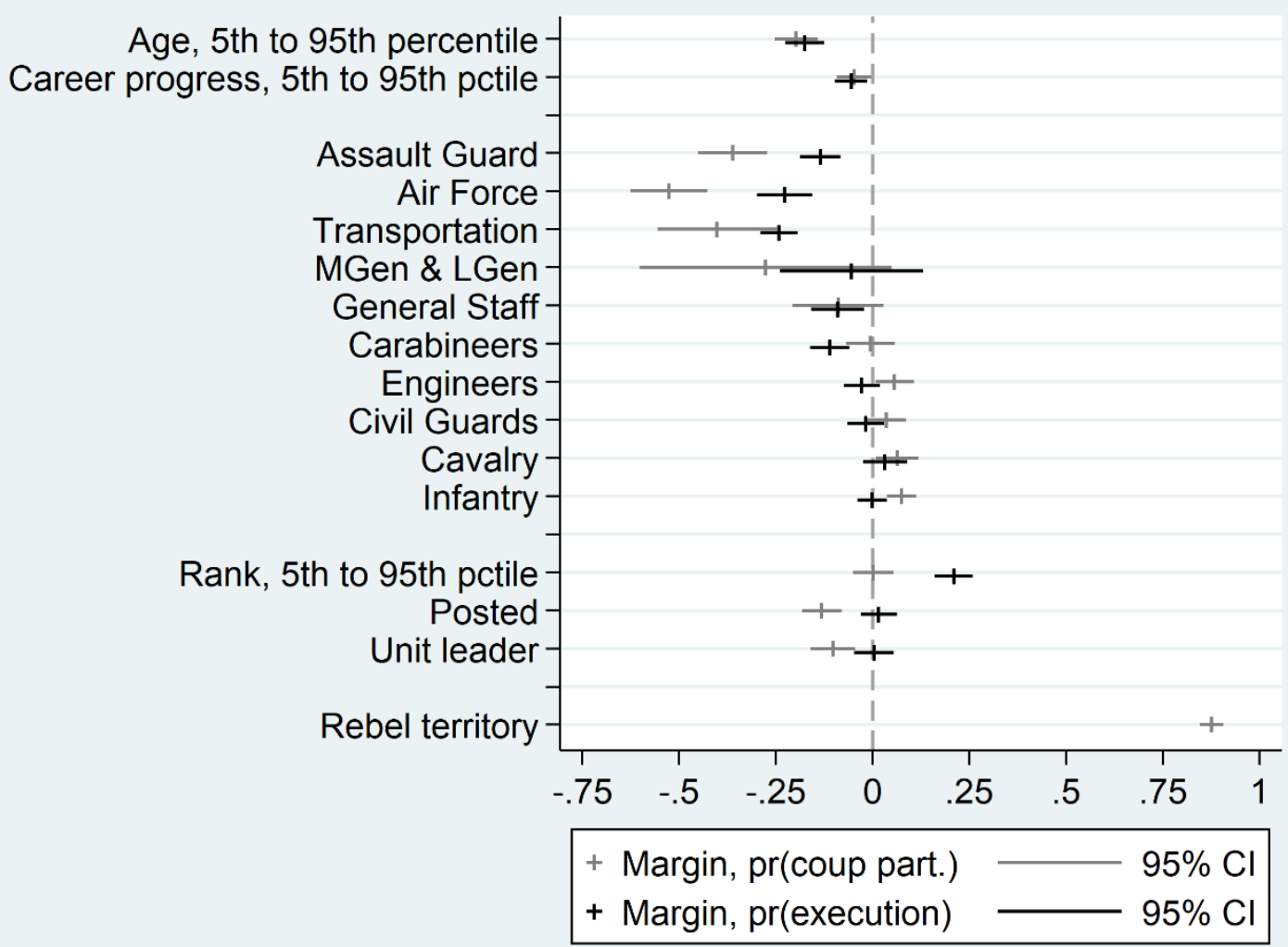

A comparison of the models of successful coup participation and execution shows promise for the logic of narrowly selective violence. Executions were related to indicators of the likelihood of disloyalty - youth, poorer recent career progress, and affiliation to a rebellious corps (here, Artillery is the baseline). Indeed, it is striking that age and recent career progress have very similar relationships with execution and with successful coup participation. The impact of corps appears somewhat diminished, in contrast: there is less variation in the execution rate across corps than there is in the coup participation rate. In general, then, executions appeared systematically related to the probability of joining the coup. Narrowly selective violence appears to have played an important role.

The costs of execution seem to have had an impact as well: the Republic executed highranking, posted officers and unit leaders disproportionately, compared to their actual participation in the coup attempt. 
Finally, the larger the errors in the model above, the more likely it is that unlikely defectors were shot. However, just assessing these errors across the Republic is uninformative, because we do not have anything to compare to. It is not obvious what degree of error would indicate that, for example, personal vendettas or stereotypes against all officers had an impact, rather than simply indicating that we have imperfect indicators of the likelihood and costs of disloyalty. However, we can develop and test hypotheses about where other logics should be more at play, and hence where the errors should be larger. This is the task of the next section.

\section{Different logics of violence in different areas}

While the analysis across the Republic suggests that narrowly selective violence explains many executions of officers, there are strong reasons to analyze whether this pattern varied across areas. The narrative above makes clear that processes of violence were very often highly local. The breakdown in central authority made it hard to apply a single pattern of violence across areas. These decisions were often in the hands of local governments, revolutionary committees that had seized power at a local level, or locally-organized militias. Unions - that is, organizations who had fought long battles with the armed forces in the leadup to war and were now typically armed - varied widely in size and political influence from place to place. And even in territory held by the Republic, the coup plotters had very different degrees of success: in some garrisons only a few officers rose, while in others, loyalist officers, soldiers and militia members fought intense street battles and sieges to put down the rising. These factors should all lead us to expect that-as with violence against civilians in the Spanish Civil War more generally-violence against officers should have different patterns from place to place.

We hypothesize that local practices of violence should vary, first, with the coup participation rate. Given a general belief that most officers might be disloyal, in a province where few actually participated in the coup suspicion may still fall on the rest. Indeed, as we argue above, these officers may well be under more suspicion than their fellow officers in places with high rates of coup participation. Staying loyal is more meaningful if it demands that you resist more of your comrades. In contrast, with a low local rate of coup participation, it may be harder to sort out who stayed out of conviction and who stayed out of peer pressure. This lack of information, in turn, would create considerable room for killing non-defectors, especially since central Republican authorities had very limited administrative capacity to gather reliable information.

Hence: 
H1. The lower the rate of successful coup participation in a given province, the more likely it is that an officer will be a victim of violence despite having a low probability of participation in the coup attempt.

In contrast to this hypothesis, executions could be equally narrowly selective across provinces, and thus have the same relationship to the estimated probability of coup participation in lowparticipation and in high-participation provinces.

The logic of stereotypes also suggests that local political dynamics may have driven violence against unlikely defectors. The onset of the SCW led to revolutionary violence; the breakdown of the state enabled local union committees to seize power in many areas on the Republican side, and across the Republic, union-organized militias took arms to fight against the rebels. Standard accounts of the war suggest that these revolutionary actors frequently targeted officers alongside other conservative social forces, portraying them as probable traitors to the Republic, and that the violence committed was often personal in nature, under the cover of targeting class enemies. One way to proxy for the strength of leftists in different areas is by looking at the strength of workers' organizations in each province. Unions were better able to act when they were already present at the outset of the war. This way of gaining leverage through local variation follows observations by Balcells (2010) and Herreros and Criado (2009) that the civil war created opportunities for local actors to pursue ideological conflicts, depending importantly on the strength that they enjoyed when the war began. We therefore hypothesize:

H2. The greater the unionization at the start of the war in a given province, the more likely it is that an officer will be a victim of violence despite having a low probability of participation in the coup attempt.

The measure of unionization in the province is the per-capita membership in the CNT (anarchist) and UGT (socialist) union confederations before 1936, in data available from Herreros and Criado (2009).

Since, again, we cannot tell who among the executed had actually tried to defect, we assess this probabilistically, based on the ability of a model of coup participation to predict executions. First, we build a limited model of successful coup participation, based on three key indicators (age, recent career progress, and corps), and test its ability to predict executions. To focus attention on the likelihood of defection and not on the costs of defection, which, as shown, did shape executions, we hold the measures of cost constant by only examining the two lowest ranks ( $2^{\text {nd }}$ lieutenants and lieutenants) and only those officers with a posting and who were not unit leaders (the modal categories of each variable). 
We estimate our model of coup participation across Spain, including a dummy for being in Rebel-controlled territory to account for following the local trend (since all our officers in our execution dataset are in Republican territory, their relative likelihood of coup participation is unaffected). Coefficient estimates are shown in the appendix. We use this model to predict the probability of coup participation for officers who did not successfully join the rebels at the outset of the war and thus could have been executed. In other words, based on what we know about those who successfully joined the coup, we assign each officer a score for how likely he was to have tried to join the coup too. We then examine how well this predicted probability of coup participation predicts execution. If it matches well, it suggests that executed officers had tried to join the coup and were caught doing so-our definition of narrowly selective violence. H1 thus expects that this should be a poorer predictor in provinces with lower rates of successful coup participation.

First, we examine the area under the Receiver Operator Characteristic (ROC) curve, comparing it across quartiles of provincial coup participation rates and of unionization rates. The area under the ROC curve is an overall indicator of predictive power, ranging from 0.5 (no better than random) to 1 (perfectly predictive). Consistent with expectations, the area under the ROC curve is greatest in the highest quartile of coup participation and in the lowest quartile of unionization (Table 1).

One can visualize predictive power in the separation plots in Table 1 (see Greenhill, Ward, and Sacks 2011). Officers are ordered from left to right by predicted probability of coup participation, which is plotted in the continuous line. The vertical lines are black if the officer was executed, white if not (lines are thicker where $\mathrm{N}$ is lower, because each officer takes up a larger share of space in the plot). The triangle at the bottom marks the expected number of executions, measuring from the right hand side. When black lines are concentrated on the right hand side of the plot, it shows that officers who were predicted to be more prone to defect were shot more often. When black lines are instead spread out on the left hand side, it shows that officers who were less likely to participate in the coup were shot anyhow. Inspection shows that the model is more predictive in higher-participation and lower-unionization provinces. In particular, just because the odds of an officer's joining the coup attempt were slim, that did not make him safe everywhere. Such officers were a good deal safer in provinces where more of their fellow officers joined the coup successfully and where there was less unionization. Unlikely defectors were shot more frequently where information about preferences was less clear and where actors pushing stereotypes of disloyalty were stronger. In the Appendix, we show that these differences across provinces are statistically significant, and that, though unionization and coup participation are 
strongly (negatively) correlated, they both seem to play an independent role in these executions of unlikely defectors.

\section{Table 1. How well a model of coup participation predicts execution, across provinces}

\begin{tabular}{|c|c|c|}
\hline $\begin{array}{l}\text { Rate of successful } \\
\text { coup participation }\end{array}$ & $\begin{array}{l}\text { Area under the } \\
\text { ROC curve } \\
\text { (s.e.) }\end{array}$ & Separation plot \\
\hline $\begin{array}{l}\text { First quartile } \\
(3.7 \%-8.6 \%)\end{array}$ & $\begin{array}{l}.653 \\
(.031)\end{array}$ & \\
\hline $\begin{array}{l}\text { Second quartile } \\
(8.6 \%-16.3 \%)\end{array}$ & $\begin{array}{l}.659 \\
(.018)\end{array}$ & \\
\hline $\begin{array}{l}\text { Third quartile } \\
(16.3 \%-27.4 \%)\end{array}$ & $\begin{array}{l}.644 \\
(.043)\end{array}$ & \\
\hline $\begin{array}{l}\text { Fourth quartile } \\
(27.4 \%-72.9 \%)\end{array}$ & $\begin{array}{l}.791 \\
(.039)\end{array}$ & \\
\hline $\begin{array}{l}\text { Rate of } \\
\text { unionization }\end{array}$ & $\begin{array}{l}\text { Area under the } \\
\text { ROC curve } \\
\text { (s.e.) }\end{array}$ & Separation plot \\
\hline $\begin{array}{l}\text { First quartile } \\
(1.1 \%-2.9 \%)\end{array}$ & $\begin{array}{l}.826 \\
(.032)\end{array}$ & \\
\hline $\begin{array}{l}\text { Second quartile } \\
(2.9 \%-4.4 \%)\end{array}$ & $\begin{array}{c}.669 \\
(.042)\end{array}$ & \\
\hline $\begin{array}{l}\text { Third quartile } \\
(4.4 \%-6.0 \%)\end{array}$ & $\begin{array}{l}.687 \\
(.024)\end{array}$ & \\
\hline $\begin{array}{l}\text { Fourth quartile } \\
(6.0 \%-16.4 \%)\end{array}$ & $\begin{array}{l}.628 \\
(.021)\end{array}$ & \\
\hline
\end{tabular}

This analysis suggests that both a lack of information and social and political forces are important drivers of violence against unlikely defectors. In contrast, if this violence only had to do with a lack of information, we would not expect the trend we observe with unionization. Stereotypes come from social processes and political actors push them. Moreover, if group enmity towards officers as a class was enough to drive killings, we would not expect unlikely coup participants to be relatively safe in units where many fellow officers were defecting. Our findings suggest that stereotypes can be overcome to some degree through better information. Ignorance, organizational failures and purely personal vendettas that do not take advantage of stereotypes would also not predict these systematic differences from place to place in killings of unlikely defectors.

This indirect strategy does raise some concerns about validity. First, in any given case, we cannot say whether an officer who was executed had actually tried to join the rebels; we can simply estimate the likelihood that that is so. However, this is of a piece with the general 
difficulty of detecting actual disloyal behavior; Kalyvas and Kocher (2007), similarly, have to impose some assumptions to assess the accuracy of violence in Vietnam. Our approach also works in terms of finding an underlying tendency or propensity to defect. Our estimates of this tendency may suffer from omitted variable bias; for example, we have no direct indicator of the officer's ideology, which may have played an important role beyond age and career progress. Further, contingent factors often mean that someone who is inclined to defect chooses not to, or vice versa. As Singh (2014) argues, coups are not elections; in particular, officers often follow the local trend in order to stay safe. Still, in a case like Spain, in which the coup divided the army, many of these contingent factors likely wash out when averaging over the whole set of officers, allowing us to detect a general tendency. In order to increase our assurance that the result is not due to locally contingent factors, in the Appendix we estimate the probability of coup participation based only on the provinces in the middle third of the range of local coup participation, where officers would have had a freer choice of which side to join, and with province-level fixed effects to control for unobserved local conditions. The results are substantially the same as here.

The Appendix adds other robustness checks too. In order to address concerns that our model of coup participation reflects intra-military stereotypes about corps affiliations rather than real defections, we repeated the analysis excluding the corps variable and focusing only on the largest corps, the infantry; results are the same. Along similar lines, we separate the effects of the three variables making up the predictive model (career progress, age, and corps), and show that the result is being driven by the first two, which were not especially subject to stereotypes. This analysis also suggests that our results are not being driven just by a predictive model that excludes key variables, with these other variables becoming important in low-coup-participation and high-unionization provinces; the substantive relationship between execution and our key correlates of coup participation decreases in these provinces, suggesting that execution just had less to do with the likelihood of joining the coup in these areas. Finally, we present evidence against an endogenous relationship, in which narrowly selective executions would drive coup participation rather than vice versa.

\section{Conclusion}

Overall, the evidence suggests that in the Spanish Republic, fears of disloyalty drove executions in different ways. Within the broad heading of disloyalty, we uncover evidence that both likely and unlikely defectors were executed. We further find that unlikely defectors are more 
likely to be shot in places with fewer actual instances of coup participation and with the presence of political forces opposed to the class of victims in question. The first finding suggests some nuance about the idea that poorly targeted violence responds to fear and threat. The general threat of disloyalty the Republic faced may separate this case from others in which suspicion is less grave; this is the war, after all, that gave us the term "fifth column." However, within this case, the loyal appear most vulnerable where disloyal behavior was least manifest. Instead, in our analysis, it appears that disproportionate violence is something that emerges when there is a general climate of fear but without immediate, concrete and obvious acts of disloyalty, for it is there that stereotypes have their strongest impact as an information shortcut. It may therefore be a product of a kind of undirected fear, legitimizing the targeting of whole categories of victims without being able to point to concrete acts of disloyalty. In addition, the presence of political actors hostile to a group of soldiers can lead to violence against those soldiers, suggesting that this is not just a strategic matter of rooting out the disloyal in conditions of uncertainty, but a factional conflict too. In turn, violence may have further effects on soldiers' behavior. Elsewhere, we find that violence against officers in the SCW provoked their unit-mates to defect (McLauchlin 2017).

The evidence uncovered here suggests a strategic logic of violence informed by sociallyconstructed and politically-reinforced information. This analysis could potentially inform our understanding of other cases in which there are serious questions about military loyalty and intense stereotypes, such as suspicions about aristocratic officers after the French Revolution (Lynn 1984), or Sunni personnel in Syria (Bou Nassif 2015). The stereotypes resulting in violence are thus likely to be specific to each context.

Violence in republican-controlled territories during the SCW has often been attributed to uncontrollable elements after the Republican state collapsed in July 1936, as opposed to the more systematic extermination performed at rebel-controlled territories (Preston 2007, 125; Reig Tapia 1986, 129, 135, 150). Some historians favored a different view in which Republican repression, far from being the result of criminals or uncontrolled elements, was performed by groups of revolutionary parties that acted with the consent or under the coordination of Republican authorities (Payne 1970, 225-26). Our work suggests a more nuanced picture that contains elements of both sides. We find evidence for killing loyal officers in areas with a stronger presence of leftist organizations, which is consistent with a "revolutionary rationality" aimed at getting rid of any member of the army. It would be wrong, however, to attribute this violence only to the political agendas of some leftist actors. Our results also suggest that it was more widespread in areas with low information about officers' loyalties resulting from lower 
participation rates of officers in the coup. Also, the breakdown of the republican order and informational asymmetries did not completely eliminate republicans' ability to target likely participants in the coup, something that does not squarely fit with any of the two extremes highlighted above. Our results are consistent with narrowly selective violence playing a role in Republican territories. This suggests that violence was driven by strategic considerations about finding one's enemies, though informed by stereotypes. More research is needed to increase our understanding of violence in Republican Spain during the SCW: do similar results apply to other groups (for example, clergy)?

It is worth emphasizing that nothing in this paper is a normative argument for what Republican authorities and militias did. Suspicion, even confirmed disloyalty, does not necessitate execution. It still requires a decision to pull the trigger, and hence to go beyond other measures to limit the risk from disloyalty, from dismissal to imprisonment to exile. For one quarter of the officers on Republican territory, someone decided to shoot. This reflects a process - both social and strategic — by which officers in general became acceptable targets. 


\section{Bibliography}

Alpert, Michael. 2013. The Republican Army in the Spanish Civil War, 1936-1939. Cambridge: Cambridge University Press.

Bakke, Kristin M., Kathleen Gallagher Cunningham, and Lee J. M. Seymour. 2012. "A Plague of Initials: Fragmentation, Cohesion, and Infighting in Civil Wars." Perspectives on Politics 10 (2): 265-83.

Balcells, Laia. 2010. "Rivalry and Revenge: Violence Against Civilians in Conventional Civil Wars.” International Studies Quarterly 54 (2): 291-313.

Bell, Curtis, and Jun Koga Sudduth. 2015. "The Causes and Outcomes of Coup during Civil War." Journal of Conflict Resolution, September.

Blaney, Gerald. 2003. "Between Order and Loyalty: The Civil Guard and the Spanish Second Republic, 1931-1936." In Conflict and Legality: Policing Mid-Twentieth Century Europe, edited by Gerard Oram, 42-63. London: Francis Boutle.

Bou Nassif, Hicham. 2015. "Second-Class': The Grievances of Sunni Officers in the Syrian Armed Forces." Journal of Strategic Studies 38 (5): 626-49. https://doi.org/10.1080/01402390.2015.1053604.

Boyd, Carolyn P. 1979. Praetorian Politics in Liberal Spain. Chapel Hill, NC: University of North Carolina Press.

Maves Braithwaite, Jessica, and Jun Koga Sudduth. 2016. "Military Purges and the Recurrence of Civil Conflict." Research \& Politics 3 (1).

Brooks, Risa. 1998. Political-Military Relations and the Stability of Arab Regimes. Adelphi Paper 324. London: International Institute for Strategic Studies.

Cardona, Gabriel. 1983. El Poder Militar En España Contemporanea Hasta La Guerra Civil. Madrid: Siglo XXI.

Casanova, Julián. 1999. "Rebelión y revolución." In Victimas de la Guerra civil, edited by Santos Julia, 57-186. Madrid: Temas de Hoy.

Casas de la Vega, Rafael. 1994. El Terror: Madrid 1936. Madridejos, Toledo: Editorial Fénix.

Castro Delgado, Enrique. 1965. Hombres made in Moscú. Barcelona: Luis de Caralt.

Chenoweth, Erica, and Maria J. Stephan. 2011. Why Civil Resistance Works: The Strategic Logic of Nonviolent Conflict. New York: Columbia University Press.

Cordón García, Antonio. 2008. Trayectoria. Recuerdos De Un Artillero. Edición: 1. Edición de Angel Viñas. Sevilla: Ediciones Espuela de Plata.

Costa, Dora L., and Matthew E. Kahn. 2008. Heroes and Cowards: The Social Face of War. Princeton: Princeton University Press.

Dahl, Marianne. 2016. "Military Defection.” PRIO Policy Brief 18. Oslo: Peace Research Institute Oslo.

Engel, Carlos. 2008. El Cuerpo de Oficiales En La Guerra de España. Valladolid: Alcañiz Fresno's Editores.

Fearon, James D., and David D. Laitin. 2003. "Ethnicity, Insurgency, and Civil War." American Political Science Review 97 (1): 75-90.

Fjelde, Hanne, and Desirée Nilsson. 2012. "Rebels against Rebels: Explaining Violence between Rebel Groups.” Journal of Conflict Resolution 56 (4): 604-28.

Fraser, Ronald. 1979. Blood of Spain: The Experience of Civil War, 1936-1939. London: Allen Lane. 
Geddes, Barbara, Joseph Wright, and Erica Frantz. 2014. "Autocratic Breakdown and Regime Transitions: A New Data Set." Perspectives on Politics 12 (2): 313-31.

González Calleja, Eduardo. 2012a. "Las Fuerzas de Orden Público Y La República.” In Los Militares Españoles En La Segunda República, edited by Jorge Martínez Reverte, 99-134. Madrid: Editorial Pablo Iglesias.

- 2012b. "Las fuerzas de orden público y la República." In Los Militares Españoles En La Segunda República, edited by Jorge Martínez Reverte, 99-134. Madrid: Fundación Pablo Iglesias.

Greenhill, Brian, Michael D. Ward, and Audrey Sacks. 2011. "The Separation Plot: A New Visual Method for Evaluating the Fit of Binary Models." American Journal of Political Science 55 (4): 991-1002.

Gutiérrez Sanín, Francisco, and Elisabeth Jean Wood. 2017. "What Should We Mean by 'Pattern of Political Violence'? Repertoire, Targeting, Frequency, and Technique." Perspectives on Politics $15 \quad$ (1): 20-41. https://doi.org/10.1017/S1537592716004114.

Herreros, Francisco, and Henar Criado. 2009. "Pre-Emptive or Arbitrary: Two Forms of Lethal Violence in a Civil War." Journal of Conflict Resolution 53 (3): 419-45.

Kalyvas, Stathis N. 2006. The Logic of Violence in Civil War. Cambridge: Cambridge University Press.

. 2012. "Micro-Level Studies of Violence in Civil War: Refining and Extending the Control-Collaboration Model." Terrorism and Political Violence 24 (4): 65868.

Kalyvas, Stathis N., and Matthew Adam Kocher. 2007. "How 'Free' Is Free Riding in Civil Wars? Violence, Insurgency, and the Collective Action Problem." World Politics 59 (2): 177-216.

Kaufmann, Chaim. 1996. "Intervention in Ethnic and Ideological Civil Wars: Why One Can Be Done and the Other Can't." Security Studies 6 (1): 62-101.

Koehler, Kevin, Dorothy Ohl, and Holger Albrecht. 2016. "From Disaffection to Defection: How Networks Facilitate Military Insubordination in Civil Conflict." Comparative Politics 48 (4): 439-57.

Kuran, Timur. 1995. Private Truths, Public Lies: The Social Consequences of Preference Falsification. Cambridge, MA: Harvard University Press.

La Parra-Pérez, Álvaro. 2014. "The Spanish Civil War: A New Institutional Interpretation of the Social Order and Military Factions during the Second Republic (1931-1939)." PhD dissertation, College Park, MD: University of Maryland.

La Parra-Perez, Alvaro. 2016. "Spain Is Not Different. Institutional Development and the Army in the Second Spanish Republic and Civil War." Revista Universitaria de Historia Militar 5 (9). http://ruhm.es/index.php/RUHM/article/view/155.

Ledesma, José Luis. 2007. "El 1936 Más Opaco: La Violencia En La Zona Republicana Durante La Guerra Civil Y Sus Narrativas.” Historia Social, no. 58: 151-68.

Lyall, Jason. 2014. "Why Armies Break: Explaining Mass Desertion in Conventional War." Working paper, Yale University. New Haven.

Lynn, John A. 1984. The Bayonets of the Republic: Motivation and Tactics in the Army of Revolutionary France, 1791-94. Urbana: University of Illinois Press. 
Martín Blázquez, José. 1939. I Helped Build an Army: Civil War Memoirs of a Spanish Staff Officer. London: Secker and Warburg.

McLauchlin, Theodore. 2010. "Loyalty Strategies and Military Defection in Rebellion." Comparative Politics 42 (3): 333-50.

2014. "Desertion, Terrain, and Control of the Home Front in Civil Wars." Journal of Conflict Resolution 58 (8): 1419-44.

- 2015. "Desertion and Collective Action in Civil Wars." International Studies Quarterly 59 (4): 669-79.

- 2017. "Ideologies, Violence, and Self-Fulfilling Prophecies of Disloyalty: Evidence from Spain." presented at the Annual Meeting of the International Studies Association, Baltimore, February 22.

McLauchlin, Theodore, and Wendy Pearlman. 2012. "Out-Group Conflict, In-Group Unity? Exploring the Relationship between Repression and Intramovement Cooperation." Journal of Conflict Resolution 56 (1): 41-66.

Oppenheim, Ben, Abbey Steele, Juan F. Vargas, and Michael Weintraub. 2015. "True Believers, Deserters, and Traitors: Who Leaves Insurgent Groups and Why." Journal of Conflict Resolution 59 (5): 794-823.

Parkinson, Sarah Elizabeth. 2013. "Organizing Rebellion: Rethinking High-Risk Mobilization and Social Networks in War." American Political Science Review 107 (3): 418-32.

Payne, Stanley G. 1970. The Spanish Revolution. London: Weidenfeld \& Nicolson.

Payne, Stanley G. 2006. The Collapse of the Spanish Republic, 1933-1936: Origins of the Civil War. New Haven: Yale University Press.

Piplani, Varun, and Caitlin Talmadge. 2015. "When War Helps Civil-military Relations Prolonged Interstate Conflict and the Reduced Risk of Coups." Journal of Conflict Resolution, February.

Preston, Paul. 2007. The Spanish Civil War: Reaction, Revolution, and Revenge. Revised and Expanded Edition edition. New York: W. W. Norton \& Company.

. 2012. The Spanish Holocaust: Inquisition and Extermination in TwentiethCentury Spain. New York: W.W. Norton.

Puell de la Villa, Fernando. 2012. "Julio de 1936. ¿Un Ejército Dividido?” In Los Militares Españoles En La Segunda República, edited by Jorge Martínez Reverte, 77-98. Madrid: Editorial Pablo Iglesias.

Quinlivan, James T. 1999. "Coup-Proofing: Its Practice and Consequences in the Middle East." International Security 24 (2): 131-65.

Reig Tapia, Alberto. 1986. Ideología e historia: sobre la represión franquista y la Guerra civil. Madrid: Akal.

Roessler, Philip G. 2011. "The Enemy Within: Personal Rule, Coups, and Civil Wars in Africa." World Politics 63 (2): 300-346.

Ruiz, Julius. 2009. "Seventy Years On: Historians and Repression During and After the Spanish Civil War." Journal of Contemporary History 44 (3): 449-72.

Saideman, Stephen M., and Marie-Joëlle Zahar. 2008. "Causing Security, Reducing Fear: Deterring Intra-State Violence and Assuring Government Restraint." In IntraState Conflict, Governments and Security: Dilemmas of Deterrence and Assurance, edited by Stephen M. Saideman and Marie-Joëlle Zahar, 1-19. New York: Routledge. 
Saíz Viadero, J. 1979. Crónicas Sobre La Guerra Civil En Santander. Santander: Institución Cultural de Cantabria.

Schelling, Thomas C. 1966. Arms and Influence. New Haven: Yale University Press.

Singh, Naunihal. 2014. Seizing Power: The Strategic Logic of Military Coups. Baltimore, MD: Johns Hopkins University Press.

Solé i Sabaté, Josep Maria, and Joan Villaroya Font. 1990. La Repressió a La Rereguarda de Catalunya: 1936-1939. 2 vols. Barcelona: Abadia de Montserrat.

Staniland, Paul. 2012. "Between a Rock and a Hard Place: Insurgent Fratricide, Ethnic Defection, and the Rise of Pro-State Paramilitaries." Journal of Conflict Resolution 56 (1): 16-40.

Steele, Abbey. 2009. "Seeking Safety: Avoiding Displacement and Choosing Destinations in Civil Wars." Journal of Peace Research 46 (3): 419-29. https://doi.org/10.1177/0022343309102660.

Sudduth, Jun Koga. 2017. "Strategic Logic of Elite Purges in Dictatorships." Comparative Political Studies 50 (13): 1768-1801.

Svolik, Milan W. 2012. The Politics of Authoritarian Rule. New York: Cambridge University Press.

Talmadge, Caitlin. 2015. The Dictator's Army: Battlefield Effectiveness in Authoritarian Regimes. Cornell Studies in Security Affairs. Ithaca: Cornell University Press.

Thomas, Hugh. 1961. The Spanish Civil War. New York: Harper \& Row.

Zhukov, Yuri M. 2014. "A Theory of Indiscriminate Violence." Cambridge, MA: Harvard University. 